\title{
The effects of loan growth on bank performance: Evidence from Vietnam
}

\author{
Van Dan Dang*
}

Department of Finance, Banking University of Ho Chi Minh city, 36 Ton That Dam street, Nguyen Thai Binh ward, District 1, Ho Chi Minh city, Vietnam

\begin{tabular}{l}
\hline C H R O N I C L E \\
\hline Article history: \\
Received: January 4, 2019 \\
Received in revised format: Feb- \\
ruary 19, 2019 \\
Accepted: February 27, 2019 \\
Available online: \\
February 27, 2019 \\
\hline Keywords: \\
Bank solvency \\
Credit risk \\
Loan growth \\
Performance \\
Profitability \\
Vietnam
\end{tabular}

\section{A B S T R A C T}

The study examines how loan growth affects performance of banks, in the form of credit risk, bank profitability and bank solvency in Vietnam during the period from 2006 to 2017. Overall, the regression results by both static and dynamic panel data models provide some evidence that loan growth indicators could have the great impacts on bank performance. In particular, growth in lending increases loan loss provisions from 2 to 3 subsequent years, lowers bank capital ratio the next year; while bank profitability gains positive effects from loan growth both in the short term and long term. These findings show the robustness when applying alternative estimation techniques. The study emphasizes the importance of caution in expanding lending activities aggressively as well as it provides implications for banks in terms of risk governance and capital management.

(C) 2019 by the authors; licensee Growing Science, Canada

\section{Introduction}

The banking system plays an important role in financing economic growth. However, the banking crisis may drag the whole economy into recession. The consequence of the global financial crisis in 2008 is a clear proof, highlighting the importance of maintaining a safe and sound banking system (Ho et al., 2016). Over-lending to the economy is a major concern in this context. This causes overextended credit supply exceeding the borrower's ability to repay and greatly affects performance of banks. Also being a business aimed at profitability, banks absolutely have reason to expand their lending activities. Bank loans can help businesses maintain and expand operations, generate profits and thereby promote the economy to grow. As a result, banks will have conditions to continue their activities stably, effectively and minimize risks. However, in case banks expand their lending aggressively, such a stable cycle may not take place and concerns about poor performance may appear. Altunbas et al. (2010) state that despite having different management systems, banks are similar to other businesses in terms of underestimating the risk to earn more profits, thus creating more potential troubles. Accordingly, the riskiness of loan growth has attracted the attention of researchers.

* Corresponding author. Tel. : +84903074850

E-mail address: dandv1978@yahoo.com (V.D.Dang) 
In developing countries, bank credit is seen as a driving force for economic growth. Large amounts of money flowing into the economy through state-controlled banks lead to significant credit growth rate which is considered the national key indicator $(\mathrm{Vo}, 2018)$. In a fairly comprehensive study of loan growth, Foos et al. (2010) find out that in most major OECD countries, high loan growth has caused greater risks for banks in subsequent years, implying that the implementation of rapid loan growth strategies make banks to face more poor performance. Is this true for emerging countries? This issue is raised in the context that banks in Asia since the 1997 financial crisis have had to operate under stricter regulations and tighter risk management policies (Pattarathammas \& Mongkonkiattichai, 2012). In addition, it is observed that banks tend to narrow lending activities when local authorities have significant influences on banks' behaviour (Qian et al., 2015) in emerging country. A comprehensive study in an emerging country as Vietnam is expected to answer this question.

Since joining WTO in 2007, Vietnam's economy has faced reform challenges to comply with new requirements (Waal et al., 2009). By much effort, Vietnam has achieved high and stable economic growth rates, based on the harmonious political system and well-controlled macroeconomic factors. The banking system restructuring process since 2012 has been considered to achieve certain achievements (Nguyen et al., 2015). However, the Vietnamese banking system still faces many challenges and difficulties. The dominance of state-owned banks (Batten \& Vo, 2016) or credit quality and bad debt handling are major concerns. The loan portfolio of banks in Vietnam is relatively risky due to high level of concentration on several economic industries (Dang \& Huynh, 2019). The rapid loan growth has created capital burdens on banks (Vo, 2018). Loan growth rate is a very important indicator in monetary policy management of State Bank of Vietnam which assigns an annual credit growth quota for each bank based on an assessment of each bank's performance. Besides, it is worth noting that the Vietnamese banking system appears to be quite slow compared to other countries' banks in terms of applying Basel II standards since capital adequacy ratios are only applied pilotly at several banks.

This study is relatively related to the existing literature on investigating whether expanding lending activities is a sign of the riskiness and poor performance of banks. Some studies which are considered to be comprehensive on this topic, such as those of Hess et al. (2009), Foos et al. (2010) and Amador et al. (2013), use the abnormal loan growth measure to represent bank lending expansion. Accordingly, Foos et al. (2010) define abnormal loan growth as "the difference between an individual bank's loan growth and a median loan growth of banks from the same country and year", while the other authors also have similar implications. According to the analysis of Laidroo and Männasoo (2013), this determination has some disadvantages that make the relationship between abnormal loan growth and loan loss provisions become weaker, ignore the bank-specific differences of loan growth problems as well as long-term growth trends in the banking market are difficult to determine. Our study pays great attention to this point and choose to apply general loan growth for research. Besides, compared to other current studies, this study has some outstanding points. To the best of our knowledge, there remains limited literature looking at the overall impact of loan growth on credit quality, bank solvency and bank return. This study incorporates these aspects instead of focusing on each separate factor with the purpose to capture bank performance. The study also offers insights into the debate on nature of loan growth in a single emerging country which owns a banking system with all the necessary features to conduct surveys, such as high credit growth periods and bad debt problems. Moreover, to increase the reliability of the regression results, the study also applies alternative techniques to check robustness. Both adding macroeconomic variables into regression models and using Z-score performance measure rarely used in studies of the same topic all show the consistency of regression results.

Previously-noted features could be viewed as certain contributions of this study into the existing literature on investigating the risky nature of loan growth toward bank performance. In addition, the findings also provide essential implications for bank managers and policymakers to be aware of the duality of rapid loan growth as well as the urgent need for risk governance and capital management. These are strongly significant evidences for emerging countries where economic growth is primarily financed by bank loans. 
More especially, the current field attracts great attention in Vietnam, a country which is applying Basel II standards pilotly before attempting to deploy synchronously in the near future. The remainder of this study will be deployed as follows. Section 2 reviews current literature and then develops hypotheses. Section 3 presents methods to achieve the research objectives. The regression results are reported in Section 4 along with the discussions before the conclusions are stated in Section 5.

\section{Literature review and hypothesis development}

It is possible to explain the research issue by many different theoretical foundations. First, the relationship between loan growth and risks could follow "herd behaviour". Rajan (1994) argues that banks tend to compete with competitors in lending with the expectation that they will not be inferior. This competition makes it easier for them to apply a more liberal credit policy by extending the borrowing limits and loosening lending conditions, thus explaining the increased risk for banks to expand credit activities. The literature also mentions factors related to the perception and behavior of banks. Guttentag and Herring (1986) argue that although banks could improve performance through fully understanding the markets, economic industries and borrowers' information, but have limitation in terms of orientation and subjective psychology when underestimating the likelihood of occurrences of low-probability events. Banks may have the necessary information for management and decision-making but tend to interpret in a biased way, reinforcing their existing beliefs about the market and borrowers. Borio et al. (2001) state that such issues of awareness and behavior will lead to wrong decisions and cause risks in the process of expanding credit at banks.

Another issue relating to shareholders and bank managers is that their platforms of goals and benefits are heterogeneous. Associated with short-term interests, bank managers could offer risky strategies to banks during the period of loan growth (Saunders et al., 1990). The loan volumes and its growth rates are the main concerns of bank managers as they are criteria to measure management performance. The rapid loan growth in the short term could create benefits for bank managers who foresee their management tenure, while in the long term risk is usually hidden for bank shareholders and successors. The importance of collateral is also considered to be an explanation for the potential poor performance that loan growth may predict. When banks extend the borrowing limit for customers, the collateral is valued up (or vice versa), leading to the fact that asset price cycle tends to go along with the loan growth cycle (Kiyotaki \& Moore, 1997). As a result, the increase in collateral price causes banks to ultimately finance the borrowers who originally do not meet the lending conditions. Since then, whenever there is a decline in collateral price, banks immediately face risks. Adrian and Shin (2010) argue that in the upward trend of the credit cycle, banks depending too much on collateral often look for new customers as all existing borrowers are having collaterals. Thus, these banks face adverse selection since they may finance bad borrowers. This theoretical framework could relate to the increase in real estate prices in some countries. Massive credit boosts real estate prices (real estate perform the roles of borrowing plan and collateral) and once the value of real estate declines, risks are inevitable.

Investigating the effects of loan growth has also been implemented by empirical studies. Keeton (1999) is one of the pioneers studying this issue. Through the dataset of US banks from 1982 to 1996, the author finds that loan growth leads to more loan loss provisions afterwards. Some conditions supporting the finding are a shift in loan supply such as a decline in lending interest rates or loosened lending standards. Salas and Saurina (2002) employ a sample from Spanish commercial and savings banks during the period 1985-1997. Their study reveals that the loan growth of banks is significantly correlated with loan loss provisions in 3 to 4 subsequent years, implying a positive relationship with lags between lending expansion and credit risk for Spanish banks. Another study conducted in Australia by Hess et al. (2008) uses data of banks from 1980 to 2005. The results conclude that current rapid loan growth results in more losses for banks after 2 to 4 years. These authors also demonstrate that in the context of macroeconomic instability or for large banks, this impact is amplified. 
Apart from other studies focusing mainly on loan growth, Laidroo and Mannasoo (2013) analyse the association between loan loss provisions ratio and the expansion of credit supply measured by unused committed credit lines. Using a dataset from 2004 to 2010 in Central and Eastern Europe, the authors find a strong positive impact with a one-year lag of credit supply expansion on credit risk measured by different methods. Foos et al. (2010) examine bank riskiness and loan growth in a study which has been considered relatively comprehensive. Using a big dataset of 16,000 banks during the period from 1997 to 2007, they conclude that loan growth is a very good indicator of bank riskiness. More specifically, their empirical results show an inverse correlation between loan growth and loan loss provisions with a one-year lag, but this effect reverses from 2 to 3 years later. Meanwhile, they also find that the rapid lending expansion makes bank solvency decline shortly, on the basis that they previously prove to protect their view points and research results that loan growth does not lower the ratio of bank capital by default, which most people assume. As they argue, in the case that banks expand lending effectively, the profits generated will be added to bank equity, not necessarily reducing the bank capital. In a relatively rare study on risk-taking behaviour of banks in non-developed countries, Kashif et al. (2016) suggest that the continuous loan growth in Pakistan during the 2006-2014 period results in more non-performing loans and worse bank solvency in the long term. They also discuss about the ineffective supervision in the context of strong competition in the banking market and most banks are subjective with potential risks during period of the credit boom. However, contrary to most of other authors, a study by Laeven and Majnoni (2003) shows that banks report less loan loss provisions in the good times of the business cycle and are forced to excessive loan loss provisions in bad times. They find out the negative relationship between loan growth and loan losses by dataset from 45 countries with more than 1,000 banks in the period from 1988 to 1999. Previously, Cavallo and Majnoni (2001) also have similar findings when studying 1,176 large commercial banks and most are from developed countries.

In summary, the impact of lending behaviours measured by loan growth could be viewed as a potential driver of poor performance in terms of both theory and practice. Following this study's initial goal, the author develops hypotheses as follows:

Hypothesis 1. There exists the positive lagged impact of loan growth on banks' loan loss provisions. Hypothesis 2. There exists the negative lagged impact of loan growth on bank solvency.

The core activities of banks are to mobilize deposits and then lend to borrowers, which creates interest income. This source of income always accounts for a large proportion of the total bank revenue. Accelerating lending activities could help banks expand market shares, increase profits and thus improve business performance as a whole. However, high loan growth tends to accompany poor lending decisions and thereby negatively influences bank profitability. Also in their study, Foos et al. (2010) find that loan growth has a negative impact on both interest income and risk-adjusted interest income, implying that loan growth is an important driver of bank performance. Paul et al. (2016) study a sample of both primary and secondary data of 31 Kenyan commercial banks between 2011 and 2015. Through relatively limited dataset, they also point out that the expansion of the banks' loan portfolio had a insignificantly positive impact on the current financial performance of banks, but had a significantly negative impact on subsequent years. Another study is that of Fahlenbrach et al. (2016) who analyse the US banking system from 1973 to 2014. They find that during this period, banks have high loan growth in a certain year will be ineffective in the third year afterwards, observed through a decline in ROA. The authors also conclude that banks having slowly lending expansion tend to have better outcome than massively growing banks. More generally, a great deal of literature focusing on the impact of rapid growth on profits shows that more growing companies have lower profits in the future. The study by Hou et al. (2014) shows that companies growing more have lower profits than those grow less. Previously, Cooper et al. (2008) conclude that asset growth is the predictor of future extraordinary profits. Despite significant differences and similarities, the findings of the mentioned studies have elicited the test hypothesis as loan growth is expected to predict potential poor performance of banks in terms of lower return. To achieve research objective, we have the following hypothesis: 
Hypothesis 3. There exists the negative lagged impact of loan growth on bank profitability.

\section{Methodology}

\subsection{Model}

The research model is based on the background theory constructed by Keeton (1999) and then it is developed according to relevant research strands to assess the overall impact of loan growth on credit risk, bank solvency and bank profitability. First, the following baseline estimation model explores loan growth and credit risk:

$\operatorname{LLP}_{\mathrm{i}, \mathrm{t}}=\alpha+\beta \times \operatorname{LLP}_{\mathrm{i}, \mathrm{t}-1}+\sum_{\mathrm{k}=1}^{3} \gamma_{\mathrm{k}} \times \mathrm{LGR}_{\mathrm{i},-\mathrm{k}}+\delta \times \mathrm{Bank}_{\mathrm{i}, \mathrm{-1}}+\varepsilon_{\mathrm{it}}$,

where $\beta, \gamma$ and $\delta$ are regression coefficients of explanatory variables and the error term $\varepsilon_{i t}$ represents unobservable effects. The dependent variable is LLP, which represents the banks' credit risk and is measured by the rate of loan loss provisions to customer loans (Cavallo \& Majnoni, 2001; Hess et al., 2009; Laidroo \& Männasoo, 2013). The study does not consider other loan types such as interbank loans, since the risk-return structure may be different. The one-year lag of the dependent variable is added into the model as an independent variable, implying that there is an impact of credit risk from one period to the next. Loan loss provisions could express the risk management quality of banks and we usually refer to this indicator to assess credit quality for the next period. The explanatory variable is LGR, which represents the banks' growth in customer loans (Keeton, 1999; Gambacorta \& Marques-Ibanez, 2011; Kashif et al., 2016). This is a very important indicator for bank lending behaviour, especially in emerging markets like Vietnam with strict control of credit growth from the government. Similar to previous studies, this study also considers the effects of loan growth with lags up to three years $(\mathrm{k}=1,2$ and 3$)$, expecting to find lagged impact as stated. Vector Bank represents a group of control variables that are bank-specific factors, which are shown in many studies to affect the safety and soundess of banks (Bertay et al., 2013; Cohen \& Scatigna, 2016; Kashif et al., 2016). Accordingly, CAP is a proxy for bank solvency, measured by total equity bank divided by total assets, due to the availability of data (instead of the sum of tier 1 capital and tier 2 capital divided by risk-weighted assets). SIZE represents bank size, calculated as the natural logarithm of the total assets. We take one-year lag of all independent variables, on the basis that banks need to construct their credit portfolio structure in advance and this structure also takes time to show the outcome (Roulet, 2018). The mentioned CAP variable plays a role as the dependent variable in the following model to investigate the impact of loan growth on bank solvency:

$\mathrm{CAP}_{\mathrm{i}, \mathrm{t}}=\alpha+\sum_{\mathrm{k}=1}^{3} \gamma_{\mathrm{k}} \times \mathrm{LGR}_{\mathrm{i}, \mathrm{t}-\mathrm{k}}+\delta \times \mathrm{Bank}_{\mathrm{i}, \mathrm{t}-\mathrm{i}}+\varepsilon_{\mathrm{it}}$

where three lags of LGR variable are expected to show the impact on bank capital in subsequent years $(\mathrm{k}=1,2$ and 3). Vector Bank now has only SIZE variable. Next, to estimate how loan growth impacts bank profitability, the study proceeds to set up the regression model as follows:

PROFIT $_{\mathrm{i}, \mathrm{t}}=\alpha+\sum_{\mathrm{k}=1}^{3} \gamma_{\mathrm{k}} \times \mathrm{LGR}_{\mathrm{i}, \mathrm{-k}}+\delta \times$ Bank $_{\mathrm{i}, \mathrm{t}-\mathrm{l}}+\varepsilon_{\mathrm{it}}$,

where PROFIT represents bank profitability, measured by ROA and ROE, seperately. ROA and ROE are calculated as net income on assets and equity, respectively. These indicators are widely used in assessment of bank profitability, but unlike Foos et al. (2010) in choosing interest income as dependent variable for their study. In this study, the author expects the indicators reflecting the overall profitability, such as ROA and ROE, to be in line with the context of the Vietnamese banking market as the noninterest income is increasing and cross-selling activities based on customer loans are becoming more popular. 
To increase the reliability of tests, the study incorporates robustness check techniques. Accordingly, we add macroeconomic factor - GDP growth rate (GDP variable in vector Macro) into Eq. (1). Meanwhile, for the Eq. (2) and Eq. (3), the study employs the Z-score ratio calculated as follows:

Z-score $=\frac{\text { Return on asset }+ \text { Equity/Asset }}{\text { Standard deviation of Return on asset }}$

The Z-score ratio has been widely used with the aim of expressing the overall performance of financial institutions or measuring bank stability (Houston et al., 2010; Delis et al., 2014; Khan et al., 2017). Banks achieving high profitability (high ROA rate) and good solvency (high CAP rate) also own high Z-score ratio, suggesting that these bank have the high overall performance and high stability as well. In short, we develop the following models for robustness check:

$\operatorname{LLP}_{\mathrm{i}, \mathrm{t}}=\alpha+\beta \times \operatorname{LLP}_{\mathrm{i}, \mathrm{t}-1}+\sum_{\mathrm{k}=1}^{3} \gamma_{\mathrm{k}} \times \operatorname{LGR}_{\mathrm{i},-\mathrm{k}}+\delta \times \operatorname{Bank}_{\mathrm{i}, \mathrm{t}-1}+\lambda \times \operatorname{Macro}_{\mathrm{i}, \mathrm{-1}}+\varepsilon_{\mathrm{it}}$

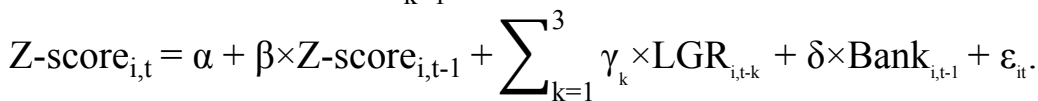

Since CAP appears in Eq. (4), we remove this variable from the Bank vector in Eq. (6) to avoid spurious regression.

\subsection{Estimation method}

We apply both system and difference generalized method of moments (S-GMM and D-GMM) to estimate correlation coefficients in Eq. (1), Eq. (5) and Eq. (6). These methods could account for dynamic nature of panel data models and solve the endogeneity problem through instrumental variables constructed inside the model (Arellano \& Bond, 1991; Arellano \& Bover, 1995). The appropriateness of GMM models is validated by Hansen/Sargan test for over identification and Arellano-Bond test for the absence of second-order autocorrelation in error term. Meanwhile, we regress Eq. (2) and Eq. (3) by pooled ordinary least squares model (Pooled OLS), fixed effect model (FEM) and random effect model (REM). Hausman test and F-test help to select a suitable regression model to solve the research problem. Heteroskedasticity and autocorrelation problems could be detected and addressed by cluster-robust standard errors (Hoechle, 2007).

\subsection{Data}

The study employs the sample of Vietnamese commercial banks. Annual financial data is collected through Bankscope for the period from 2006 to 2017. We remove banks that do not have financial information for 5 consecutive years, and also do not consider banks having mergers and acquisitions due to major fluctuations regarding asset growth and lending activities. This is consistent with the orientation of previous studies (Foos et al., 2010; Laidroo \& Männasoo, 2013). The macroeconomic information is collected from World Development Indicators (WDI). Hence, finally we have a unbalanced panel dataset including 31 Vietnamese commercial banks with total 333 observations. Table 1 presents the descriptive statistics for variables. The average annual loan growth rate is $21.70 \%$, suggesting that the size of customer loans tends to expand during overall research period. The maximum rate of loan growth observed is up to $91.88 \%$, but there is a bank that reduces $45.54 \%$ of the loan to customer in a year. The growth rate of GDP is relatively high and stable at an average of $6.14 \%$, it may be seen that the economy in an emerging country as Vietnam still relies on banks, and bank lending is an important channel to finance the economy. The average ratio of loan loss provisions over customer loans of banks in the period from 2006 to 2017 is $1.43 \%$, while the largest and smallest values are considerably different. The data also shows that the values measuring bank solvency and profitability have a wide scope of distribution, implying the difference in bank performance. 
Table 1

Summary statistics

\begin{tabular}{lccccc}
\hline Variable & Mean & Std. Dev. & Min & Max & Observations \\
\hline LGR (\%) & 21.70 & 18.84 & -45.54 & 91.88 & 333 \\
LLP (\%) & 1.43 & 2.45 & 0.012 & 43.96 & 333 \\
CAP (\%) & 10.84 & 7.35 & 1.07 & 80.07 & 333 \\
ROA (\%) & 0.84 & 0.70 & -5.51 & 4.68 & 333 \\
ROE (\%) & 8.93 & 8.24 & -82.00 & 43.20 & 333 \\
SIZE & 17.96 & 1.36 & 13.57 & 20.88 & 333 \\
Z-SCORE & 44.81 & 276.85 & 0.56 & $4,982.34$ & 333 \\
GDP (\%) & 6.14 & 0.60 & 5.24 & 7.12 & 333 \\
\hline
\end{tabular}

This table shows the summary statistics of the variables. LGR is calculated as the growth rate of bank loan for customers. LLP is a credit risk variable measured by the rate of loan loss provisions to customer loans. CAP is a proxy for bank solvency, measured by total bank equity divided by total assets. ROA and ROE are measures of bank profitability, calculated as the net income on assets and equity, respectively. SIZE represents bank size, calculated as the natural logarithm of the total assets. Z-SCORE is as a proxy of bank stability, measured by the sum of ROA and CAP on standard deviation of ROA. GDP is the GDP growth rate.

Table 2 shows the correlation coefficients matrix between the variables employed. It is possible to observe the correlation of each pair of variables, then we have a brief overview of the association between the factors studied. Notably, the variables that measure profitability and stability of banks do not show strong positive correlation (including ROA, ROE and Z-score), supporting the fact that we have to do further regressions to find out research results.

Table 2

Correlation coefficients matrix

\begin{tabular}{|c|c|c|c|c|c|c|c|c|}
\hline Variable & LGR & LLP & CAP & ROA & ROE & SIZE & Z-SCORE & GDP \\
\hline LGR & 1 & & & & & & & \\
\hline LLP & -0.00 & 1 & & & & & & \\
\hline CAP & 0.11 & -0.09 & 1 & & & & & \\
\hline ROA & 0.34 & -0.02 & 0.29 & 1 & & & & \\
\hline ROE & 0.26 & 0.08 & -0.20 & 0.71 & 1 & & & \\
\hline SIZE & -0.29 & 0.11 & -0.62 & -0.24 & 0.24 & 1 & & \\
\hline Z-SCORE & -0.03 & 0.00 & 0.52 & -0.06 & -0.07 & 0.01 & 1 & \\
\hline GDP & 0.26 & 0.03 & -0.01 & 0.04 & 0.08 & -0.02 & 0.06 & 1 \\
\hline
\end{tabular}

This table shows the correlation coefficients for the variables. LGR is calculated as the growth rate of bank loan for customers. LLP is a credit risk variable measured by the rate of loan loss provisions to customer loans. CAP is a proxy for bank solvency, measured by total bank equity divided by total assets. ROA and ROE are measures of bank profitability, calculated as the net income on assets and equity, respectively. SIZE represents bank size, calculated as the natural logarithm of the total assets. Z-SCORE is as a proxy of bank stability, measured by the sum of ROA and CAP on standard deviation of ROA. GDP is the GDP growth rate.

\section{Empirical results and discussions}

\subsection{The impact of loan growth on credit risk}

Table 3 reports the regreesion results according to Eq. (1) by D-GMM and S-GMM. The Arellano-Bond test shows that the error term has no second-order autocorrelation and the Sargan/Hansen test verifies that the hypothesis of the validity of instrumental variables could not be rejected. There exists no significant difference in the estimation results of two methods, confirming the reliability of the regression results. Accordingly, all regression coefficients of LGR variable with lags of 2 to 3 years are statistically positive and significant at the level of $1 \%$. This indicates that banks which are more aggressive in lending may face greater credit risk in 2 to 3 subsequent years, represented by a higher rate of loan loss provisions. This finding is completely consistent with the expectation stated in Hypothesis 1 and also similar to the previous findings (Salas \& Saurina, 2002; Hess et al., 2008; Foos et al., 2010). The lending expansion in current year does not immediately cause risks, but the defaults will be revealed in subsequent years. Competition pressure, government influence, or ineffective business orientation have led to a period where loan growth is almost continuous with not well-controlled speed and low credit quality. The research results contribute to the current discussion on confirming the potential riskiness of banks through loan growth proxy. 
Table 3

Regression results for loan loss provisions

\begin{tabular}{|c|c|c|}
\hline Variable & $D-G M M$ & $S-G M M$ \\
\hline $\mathrm{LLP}_{\mathrm{t}-1}$ & $\begin{array}{l}0.720 \\
(0.029)^{* * *}\end{array}$ & $\begin{array}{l}0.687 \\
(0.017)^{* * *}\end{array}$ \\
\hline $\mathrm{LGR}_{\mathrm{t}-1}$ & $\begin{array}{l}0.001 \\
(0.001)\end{array}$ & $\begin{array}{l}-0.002 \\
(0.001)^{* * *}\end{array}$ \\
\hline $\mathrm{LGR}_{\mathrm{t}-2}$ & $\begin{array}{l}0.003 \\
(0.001) * * *\end{array}$ & $\begin{array}{l}0.003 \\
(0.000)^{* * * *}\end{array}$ \\
\hline $\mathrm{LGR}_{\mathrm{t}-3}$ & $\begin{array}{l}0.003 \\
(0.001)^{* * *}\end{array}$ & $\begin{array}{l}0.003 \\
(0.000) * * *\end{array}$ \\
\hline SIZE $_{t-1}$ & $\begin{array}{l}-0.015 \\
(0.029)\end{array}$ & $\begin{array}{l}-0.007 \\
(0.025)\end{array}$ \\
\hline $\mathrm{CAP}_{\mathrm{t}-1}$ & $\begin{array}{l}-0.013 \\
(0.003)^{* * *}\end{array}$ & $\begin{array}{l}-0.013 \\
(0.005)^{* * *}\end{array}$ \\
\hline Observations & 207 & 238 \\
\hline $\mathrm{AR}(1)$ test & $\begin{array}{l}-3.248 \\
(0.001)\end{array}$ & $\begin{array}{l}-3.330 \\
(0.001)\end{array}$ \\
\hline $\mathrm{AR}(2)$ test & $\begin{array}{l}0.613 \\
(0.539)\end{array}$ & $\begin{array}{l}0.600 \\
(0.549)\end{array}$ \\
\hline Sargan test & $\begin{array}{l}25.391 \\
(0.330)\end{array}$ & \\
\hline Hansen test & & $\begin{array}{l}4.560 \\
(0.871)\end{array}$ \\
\hline
\end{tabular}

Regarding control variables, the previous year's credit risk and bank capital show regression results which are consistent with the author's expectations. The rate of loan loss provisions could be considered to represent the risk management effectiveness of banks, hence we may predict the banks' debt quality relying on this indicator. In addition, the bank capital is as expected as a buffer for banks to improve operational capacity and respond better to risks.

\subsection{The impact of loan growth on bank solvency}

Continue to examine the riskiness of loan growth by investigating the impact on bank solvency, Table 4 reports the regression results of Eq. (2) by Pooled OLS, FEM and REM estimations.

\section{Table 4}

Regression results for bank capital

\begin{tabular}{llll}
\hline Variable & Pooled OLS & $F E M$ & REM \\
\hline LGR $_{\mathrm{t}-1}$ & -0.051 & -0.052 & -0.052 \\
& $(0.023)^{* *}$ & $(0.012)^{* * *}$ & $(0.014)^{* * *}$ \\
LGR $_{\mathrm{t}-2}$ & -0.030 & -0.009 & -0.012 \\
& $(0.020)$ & $(0.010)$ & $(0.011)$ \\
LGR $_{\mathrm{t}-3}$ & -0.012 & 0.004 & 0.002 \\
& $(0.018)$ & $(0.009)$ & $(0.011)$ \\
SIZE & -3.028 & -2.977 \\
& $(0.313)^{* * *}$ & $(0.388)^{* * *}$ & $(0.418)^{* * *}$ \\
\hline Observations & 238 & 238 & 238 \\
\hline Note: This table reports the Pooled OLS, FEM and REM regression results of the equation (2), in which CAP is the dependent variable, a proxy for bank \\
solvency, which is measured by total bank equity divided by total assets; LGR is calculated as the growth rate of bank loan for customers; SIZE represents bank \\
size, calculated as the natural logarithm of the total assets. The symbols *, *, and *** represent statistical significance at the 10\%, 5\%, and 1\% level, respectively.
\end{tabular}

All estimation results show the consistency and this reinforces the reliability of the study's final conclusion. The finding reveals that the regression coefficients of the loan growth variable with a oneyear lag are statistically positive and significant at the $1 \%$ level, while further lags do not show statistical significance. This highlights that short-term loan growth has a strong negative impact on bank capital; in other words, strongly expanding lending activities will shortly make bank solvency decline. This result confirms Hypothesis 2, which is consistent with the previous study by Foos et al. (2010), however, 
slightly different from the conclusion of Kashif et al. (2016) as the study shows no long-term relationship. The finding could explain the fact that Vietnamese commercial banks after a period of aggressive lending have encountered bank capital burdens and need a long time to settle (Vo, 2018), under pressure from the state authority in requesting the adjustment of capital adequacy ratio.

\subsection{The impact of loan growth on bank profitability}

Examining the role of loan growth as a riskiness proxy of Vietnamese commercial banks has shown the results as our the expectations in terms of loan loss provisions and bank solvency. Next, Table 5 presents the regression results considering the impact of loan growth on bank profitability.

Table 5

Regression results for bank profitability

\begin{tabular}{|c|c|c|c|c|c|c|}
\hline & $F E M$ & & $R E M$ & & Adjusted FE & \\
\hline Variable & ROA & $\mathrm{ROE}$ & ROA & ROE & ROA & $\mathrm{ROE}$ \\
\hline $\mathrm{LGR}_{\mathrm{t}-1}$ & $\begin{array}{l}0.007 \\
(0.002) * * *\end{array}$ & $\begin{array}{l}0.101 \\
(0.019) * * *\end{array}$ & $\begin{array}{l}0.007 \\
(0.002)^{* * *}\end{array}$ & $\begin{array}{l}0.103 \\
(0.019) * * *\end{array}$ & $\begin{array}{l}0.007 \\
(0.001)^{* * *}\end{array}$ & $\begin{array}{l}0.101 \\
(0.009) * * *\end{array}$ \\
\hline $\mathrm{LGR}_{\mathrm{t}-2}$ & $\begin{array}{l}0.007 \\
(0.002) * * *\end{array}$ & $\begin{array}{l}0.067 \\
(0.015) * * *\end{array}$ & $\begin{array}{l}0.008 \\
(0.002)^{* * *}\end{array}$ & $\begin{array}{l}0.082 \\
(0.016) * * *\end{array}$ & $\begin{array}{l}0.007 \\
(0.001)^{* * *}\end{array}$ & $\begin{array}{l}0.067 \\
(0.009) * * *\end{array}$ \\
\hline $\mathrm{LGR}_{\mathrm{t}-3}$ & $\begin{array}{l}0.004 \\
(0.002) * * *\end{array}$ & $\begin{array}{l}0.030 \\
(0.015)^{* *}\end{array}$ & $\begin{array}{l}0.005 \\
(0.001)^{* * *}\end{array}$ & $\begin{array}{l}0.048 \\
(0.015) * * *\end{array}$ & $\begin{array}{l}0.004 \\
(0.001)^{* * *}\end{array}$ & $\begin{array}{l}0.030 \\
(0.007) * * *\end{array}$ \\
\hline SIZE $_{t-1}$ & $\begin{array}{l}-0.192 \\
(0.080)^{* *}\end{array}$ & $\begin{array}{l}-2.493 \\
(0.772)^{* * *}\end{array}$ & $\begin{array}{l}0.028 \\
(0.053)\end{array}$ & $\begin{array}{l}0.528 \\
(0.572)\end{array}$ & $\begin{array}{l}-0.192 \\
(0.075)^{* *}\end{array}$ & $\begin{array}{l}-2.493 \\
(0.964) * *\end{array}$ \\
\hline $\mathrm{CAP}_{\mathrm{t}-1}$ & $\begin{array}{l}0.018 \\
(0.010)^{*}\end{array}$ & $\begin{array}{l}-0.185 \\
(0.097)^{*}\end{array}$ & $\begin{array}{l}0.034 \\
(0.009)^{* * *}\end{array}$ & $\begin{array}{l}-0.028 \\
(0.095)\end{array}$ & $\begin{array}{l}0.018 \\
(0.011)\end{array}$ & $\begin{array}{l}-0.185 \\
(0.082)^{*}\end{array}$ \\
\hline Observations & 238 & 238 & 238 & 238 & 238 & 238 \\
\hline Heteroskedasticity & No & No & No & No & Yes & Yes \\
\hline Autocorrelation & No & No & No & No & Yes & Yes \\
\hline \multicolumn{7}{|c|}{$\begin{array}{l}\text { This table reports the FEM, REM and Adjusted FEM (standard errors are corrected using appropriate adjustments to deal with heteroskedasticity and } \\
\text { autocorrelation) regression results of the equation (3), in which ROA and ROE are the dependent variables, separately, which are measures of bank } \\
\text { profitability, calculated as the net income on assets and equity, respectively; LGR is calculated as the growth rate of bank loan for customers; CAP is a proxy } \\
\text { for bank solvency, measured by total bank equity divided by total assets; SIZE represents bank size, calculated as the natural logarithm of the total assets. All } \\
\text { F-tests and Hausman tests for the preference of appropriate model show p-value }<0.01 \text {, leading to the favour of FEM for specifications. The symbols } *, * * \text {, } \\
\text { and } * * * \text { represent statistical significance at the } 10 \%, 5 \% \text {, and } 1 \% \text { level, respectively. }\end{array}$} \\
\hline
\end{tabular}

All regression coefficients show the consistency in interpreting the significantly positive impact of the loan growth variable at any considered lag on the dependent variable ROA and ROE, separately. Thus, this result implies that the lending expansion of banks will generally cause better profitability measured by ROA and ROE, both in the short term and long term. This finding does not confirm Hypothesis 3 and shows the contrary to other studies (Foos et al., 2010; Fahlenbrach et al., 2016; Paul et al., 2016), while loan growth tends to increase loan loss provisions ratios which also increases the bank costs. Employing ROA and ROE measurements to represent bank profitability rather than interest income in other study (Foos et al., 2010) may create this difference. One more possible explanation is that the growing competition in credit activities has urged Vietnamese banks to change business strategies which focuses more on non-interest income (Nguyen et al., 2012). This gradually increasing source of income could help banks reduce risks compared to banks depending mainly on interest income. The finding also provides implications and suggests for research to explore the cross-selling effectiveness of banking products derived from the bank's lending expansion.

\subsection{Robustness checks}

Table 6 presents the robustness checks, which add macroeconomic variables (Eq. 5) and applies Z-score measurement in estimations related to profitability and bank capital (Eq. 6). Through similar arguments in Section 3.1, we employ GMM dynamic panel data model for Z-score regression. Since specification with Z-score variable by S-GMM could not pass Hansen test, we do not present the output in the table. 
Table 6

Robustness checks of regression results

\begin{tabular}{|c|c|c|c|}
\hline & \multicolumn{2}{|c|}{ LLP is the dependent variable } & Z-SCORE is the dependent variable \\
\hline Variable & D-GMM & S-GMM & D-GMM \\
\hline $\operatorname{LLP}_{t-1}$ & $\begin{array}{l}0.738 \\
(0.030)^{* * *}\end{array}$ & $\begin{array}{l}0.682 \\
(0.025) * * *\end{array}$ & \\
\hline Z-SCORE & & & $\begin{array}{l}0.383 \\
(0.024) * * *\end{array}$ \\
\hline $\mathrm{LGR}_{\mathrm{t}-1}$ & $\begin{array}{l}-0.001 \\
(0.001)^{* *}\end{array}$ & $\begin{array}{l}-0.002 \\
(0.001)^{* * *}\end{array}$ & $\begin{array}{l}-0.002 \\
(0.008)\end{array}$ \\
\hline $\mathrm{LGR}_{\mathrm{t}-2}$ & $\begin{array}{l}0.002 \\
(0.001)^{*}\end{array}$ & $\begin{array}{l}0.002 \\
(0.001)^{* * *}\end{array}$ & $\begin{array}{l}0.039 \\
(0.006) * * *\end{array}$ \\
\hline $\mathrm{LGR}_{\mathrm{t}-3}$ & $\begin{array}{l}0.004 \\
(0.001)^{* * *}\end{array}$ & $\begin{array}{l}0.003 \\
(0.000)^{* * *}\end{array}$ & $\begin{array}{l}0.037 \\
(0.006) * * *\end{array}$ \\
\hline $\mathrm{SIZE}_{\mathrm{t}-1}$ & $\begin{array}{l}-0.080 \\
(0.033)^{* *}\end{array}$ & $\begin{array}{l}-0.027 \\
(0.033)\end{array}$ & $\begin{array}{l}-1.297 \\
(0.288) * * *\end{array}$ \\
\hline $\mathrm{CAP}_{\mathrm{t}-1}$ & $\begin{array}{l}-0.016 \\
(0.003)^{* * *}\end{array}$ & $\begin{array}{l}-0.014 \\
(0.005)^{* * *}\end{array}$ & \\
\hline $\mathrm{GDP}_{\mathrm{t}-1}$ & $\begin{array}{l}0.091 \\
(0.025)^{* * *}\end{array}$ & $\begin{array}{l}0.033 \\
(0.007)^{* * *}\end{array}$ & \\
\hline Observations & 207 & 238 & 207 \\
\hline $\mathrm{AR}(1)$ test & $\begin{array}{l}-3.267 \\
(0.000)\end{array}$ & $\begin{array}{l}-3.260 \\
(0.001)\end{array}$ & $\begin{array}{l}-1.926 \\
(0.054)\end{array}$ \\
\hline $\mathrm{AR}(2)$ test & $\begin{array}{l}0.530 \\
(0.595)\end{array}$ & $\begin{array}{l}0.580 \\
(0.563)\end{array}$ & $\begin{array}{l}0.488 \\
(0.625)\end{array}$ \\
\hline Sargan test & $\begin{array}{l}23.239 \\
(0.446)\end{array}$ & & $\begin{array}{l}25.062 \\
(0.347)\end{array}$ \\
\hline Hansen test & & $\begin{array}{l}1.520 \\
(0.997)\end{array}$ & \\
\hline
\end{tabular}

Accordingly, the robustness checks show consistency with previous estimations in terms of predicting bank performance by loan growth proxy. Especially, as for Z-score regression model, the coefficients of LGR variable lagged from 2 to 3 years show the positive impact of loan growth on the bank stability, consistent with the regression applying variables that measure profitability (ROA is on the numerator in Eq. 4 defining Z-score). Meanwhile loan growth variable with a one-year lag does not show statistical significance in the context that previous regression results indicate the loan growth both reduces the bank capital ratio (CAP is also on the numerator in Eq. 4 defining Z-score) and increases profitability measured by ROA the next year. These results are very appropriate and provide further evidence of the reliability of regression estimations for decision-making.

\section{Conclusions}

Using a number of regression methods compatible with panel data models, the author has examined how loan growth drives performance of banks in Vietnam from 2006 to 2017 by hypotheses related to credit risk, bank solvency and bank profitability. The empirical results show that banks expanding lending activities aggressively tend to reduce bank solvency immediately and increase the rate of loan loss provisions in 2 to 3 subsequent years. Regarding bank profitability, the finding does not show that rapid loan growth will reduce banks' return as our initial expectation, but improves the profitability many years later instead. Major changes in business strategy of Vietnamese banks may be an appropriate explanation for this finding, which also suggests potential research in the future. In summary, the author finds out some certain supportive evidence on the hypotheses that consider loan growth as a potential driver of banks' poor performmance. Hence, banks have to be extremely cautious with their lending expansion since this is probably a threat for bank performance afterwards. Strict loan approval procedures, effective 
risk management systems of banks, along with inspection and supervision by regulatory agencies could limit bank risks related to extending loan growth aggressively. In addition, banks need to consider the maintenance of bank capital adequacy ratio as expanding lending agressively to meet regulations and strengthen capacity in the context that the Vietnamese banking system is making efforts to apply standards of Basel II. Similar to most of other studies, this study employs loan growth rate with lags for several years as explanatory variables. However, it is difficult to determine the appropriate time span for bank risks to be revealed. Recognizing bank risks may differ depending on last "bust" of loan portfolio, business cycle, credit policy in structuring loans and repayment schedules. Further lags could be taken into consideration, but this study does not examine those cases due to small sample size. These problems as well as the availability of data may be considered as research limitations.

\section{Acknowlegdement}

We are grateful to the anonymous referees for their very helpful comments and suggestions. This study is supported financially by the Banking University of Ho Chi Minh City.

\section{References}

Adrian, T., \& Shin, H. S. (2010). The changing cature of financial intermediation and the financial crisis of 2007-2009. Annual Review of Economics, 2(1), 603-618.

Altunbas, Y., Gambacorta, L., \& Marques-Ibanez, D. (2010). Bank risk and monetary policy. Journal of Financial Stability, 6(3), 121-129.

Amador, J. S., Gómez-González, J. E., \& Pabón, A. M. (2013). Loan growth and bank risk: new evidence. Financial Markets and Portfolio Management, 27(365), 365-379.

Arellano, M., \& Bond, S. (1991). Some tests of specification for panel data: Monte-Carlo evidence and an application to employment equations. Review of Economic Studies, 58(2), 277-297.

Arellano, M., \& Bover, O. (1995). Another look at the instrumental variable estimation of errorcomponents models. Journal of Econometrics, 68(1), 29-51.

Bertay, A. C., Demirgüç-Kunt, A., \& Huizinga, H. (2013). Do we need big banks? Evidence on performance, strategy and market discipline. Journal of Financial Intermediation, 22(4), 532-558.

Borio, C., Furfine, C., \& Lowe, P. (2001). Procyclicality of the financial system and financial stability: issues and policy options. BIS Paper No. 1, 1-51.

Cavallo, M., \& Majnoni, G. (2001). Do banks provision for bad loans in good times? Empirical evidence and policy implications. World Bank Policy Research Working Paper No. 2619, 1-33.

Cohen, B. H., \& Scatigna, M. (2016). Banks and capital requirements: Channels of adjustment. Journal of Banking \& Finance, 69(2016), S56-S69.

Cooper, M. J., Gulen, H., \& Schill, M. J. (2008). Asset growth and the cross-section of stock returns. The Journal of Finance, 63(4), 1609-1651.

Dang, V. D., \& Huynh, J. (2019). The effects of loan portfolio diversification on Vietnamese banks' return. In: Kreinovich, V., Thach, N., Trung, N., \& Van, T. D. (eds) Beyond Traditional Probabilistic Methods in Economics. ECONVN 2019. Studies in Computational Intelligence. 809. Springer, Cham.

Delis, M. D., Hasan, I., \& Tsionas, E. G. (2014). The risk of financial intermediaries. Journal of Banking and Finance, 44(2014), 1-12.

Fahlenbrach, R., Prilmeier, R., \& Stulz, R. M. (2016). Why does fast loan growth predict poor performance for banks?. The Review of Financial Studies, 31(3), 1014-1063.

Foos, D., Norden, L., \& Weber, M. (2010). Loan growth and riskiness of banks. Journal of Banking and Finance, 34(13), 2929-2940.

Gambacorta, L., \& Marques-Ibanez, D. (2011). The banking lending channel: Lessons from the crisis. Economic Policy, 26(66), 135-182.

Guttentag, J. M., \& Herring, R. J. (1986). Disaster Myopia in International Banking. Essays in International Finance, No. 164. International Finance section, Princeton University.

Hess, K., Grimes, A., \& Holmes, M. (2009). Credit losses in Australasian banking. Economic Record, 85(279), 331-343. 
Ho, P.-H., Huang, C.-W., Lin, C.-Y., \& Yen, J.-F. (2016). CEO overconfidence and financial crisis: evidence from bank lending and leverage. Journal of Financial Economics, 120(1), 194-209.

Hoechle, D. (2007). Robust standard errors for panel regressions with cross-sectional dependence. Stata Journal, 7(3), 281-312.

Hou, K., Xue, C., \& Zhang, L. (2015). Digesting anomalies: An investment approach. The Review of Financial Studies, 28(3), 650-705.

Houston, J. F., Lin, C., Lin, P., \& Ma, Y. (2010). Creditor rights, information sharing, and bank risk taking. Journal of Financial Economics, 96(3), 485-512.

Kashif, M., Iftikhar, S. F., \& Iftikhar, K. (2016). Loan growth and bank solvency: evidence from the Pakistani banking sector. Financial Innovation, 2(1), 1-13.

Keeton, W. R. (1999). Does faster loan growth lead to higher loan losses?. Federal Reserve Bank of Kansas City Economic Review, Second Quarter 1999, 57-75.

Khan, M. S., Scheule, H., \& Wu, E. (2017). Funding liquidity and bank risk taking. Journal of Banking \& Finance, 82, 203-216.

Kiyotaki, N., \& Moore, J. (1997). Credit cycles. Journal of Political Economy, 105(2), 211-248.

Laeven, L., \& Majnoni, G. (2003). Loan loss provisioning and economic slowdowns: too much, too late?. Journal of Financial Intermediation, 12(2), 178-197.

Laidroo, L., \& Männasoo, K. (2013). Credit growth and banks' asset quality: Evidence from Central and Eastern Europe. 5th International Conference "Economic Challenges in Enlarged Europe", Conference Proceedings, 16-18 June 2013, Tallinn.

Nguyen, H. S., Tran, T. T. T., Dinh, X. C., Lai, A. N., \& Pham, B. K. (2015). Impact of ownership structure and bank performance - An empirical test in Vietnamese banks. International Journal of Financial Research, 6(4), 123-133.

Nguyen, T. C., Vo, D. V., \& Nguyen, V. C. (2012). Risk and income diversification in the Vietnamese banking system. Journal of Applied Finance \& Banking, 5(1), 99-115.

Pattarathammas, S., \& Mongkonkiattichai, S. (2012). Loan growth and risk of Asian financial institutions after the Asian financial crisis. October 19, 2012.

Paul, K. T., Kilungu, M., \& Andrew, S. (2016). Effect of loan portfolio growth on financial performance of commercial banks in Kenya. Imperial Journal of Interdisciplinary Research, 2(11), 2113-2119.

Qian, J., Strahan, P. E., \& Yang, Z. (2015). The impact of incentives and communication costs on information production and use: Evidence from bank lending. Journal of Finance, 70(4), 1457-1493.

Rajan, R. G. (1994). Why bank credit policies fluctuate: A theory and some evidence. The Quarterly Journal of Economics, 109(2), 399-441.

Roulet, C. (2018). Basel III: Effects of capital and liquidity regulations on European bank lending. Journal of Economics and Business, 95(2018), 26-46.

Salas, V., \& Saurina, J. (2002). Credit risk in two institutional regimes: Spanish commercial and savings banks. Journal of Financial Services Research, 22(3), 203-224.

Saunders, A., Strock, E., \& Travlos, N. G. (1990). Ownership structure, deregulation, and bank risk taking. Journal of Finance, 45(2), 643-654.

Vo, X. V. (2016). Finance in Vietnam - an overview. Afro-Asian Journal of Finance and Accounting, 6(3), 202-209.

Vo, X. V. (2018). Bank lending behavior in emerging markets. Finance Research Letters, 27(2018), 129134.

Waal, A., Duong, H., \& Ton, V. (2009). High Performance in Vietnam: The Case of the Vietnamese Banking Industry. Journal of Transnational Management, 14(3), 179-201.

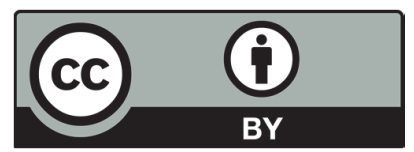

(C) 2019 by the authors; licensee Growing Science, Canada. This is an open access article distributed under the terms and conditions of the Creative Commons Attribution (CCBY) license (http://creativecommons.org/licenses/by/4.0/). 